\title{
Growing together or growing apart? \\ A village level study of the impact of the Doha round on rural China
}

\author{
Marijke Kuiper \& Frank van Tongeren \\ Agricultural Economics Research Institute (LEI) - Wageningen UR
}

Paper prepared for the $7^{\text {th }}$ Annual Conference on Global Economic Analysis, Trade, Poverty and the Environment, Washington D.C. June 17-19, 2004

First draft, May 2004

\begin{abstract}
Most studies of the opening of the Chinese economy focus on the national level. The few existing more disaggregated analyses are limited to analyzing changes in agricultural production. In this paper we employ an innovative village equilibrium model which accounts for nonseparability of household production and consumption decisions. This allows us to analyze the impact of trade liberalization on household production, consumption and off-farm employment, the interactions among these three aspects of household decisions, as well as the interactions among households in a village economy. Analyzing the impact of trade liberalization we find changes in relative prices of inputs and outputs and outside village employment to have opposite impacts on household decisions. Price changes affect the labor intensity of rice production as households switch between intensive two-season and on-season rice in response to changes in their shadow wages. Outside village employment opportunities induce a less labor intensive rice cropping. The consequent drop in demand for traction services reduces cash income for those households that do not have access to migration and thus economic growth in coastal areas affects them indirectly through the village factor market. In terms of aggregate village agricultural supply response we find the impact of the increase in employment to dominate aggregate response. As a result the marketed surplus of case study village is found to be shifting from rice to livestock.
\end{abstract}

A gradual integration in the global economy, combined with far-reaching domestic reforms, has led China to be a showcase of attaining rapid economic growth through market reforms. The rapid economic growth during the past decades, however, has been accompanied by an increasing disparity between coastal and interior regions and between rural and urban areas. The coastal cities benefited most from the increasing export opportunities, due to a combination of geographical factors and deliberate policies (Démurger et al., 2002).

The extent of reform in combination with the size of the Chinese economy, has resulted in a body of literature with a growth rate rivaling China's GDP growth. Most studies of the opening of the Chinese 
economy to the rest of the world focus at the national level. One exception is a study by Diao et al. (2003) on the regional impact of China's recent WTO accession. As in other national level studies, they find a positive aggregate effect for China as a whole. This aggregate effect obscures differences across regions. Reflecting past trends of diverging growth between coastal and inland provinces (see for example Démurger et al., 2002; Jones et al., 2003), income gaps between provinces are found to widen following WTO accession. They also find rural-urban migration providing an important mechanism for transmitting urban growth to the rural areas. Especially central provinces bordering the booming coastal provinces (Anhui, Jiangxi, Hubei and Hunan), benefit from an increase in ruralurban migration.

A second exception to the common use of a national level analysis is a study by Huang et al. (2003) analyzing the impact of WTO accession on farm households. They find that despite a small positive aggregate impact of the WTO, the distribution of benefits gives cause for concern. Households in richer coastal areas benefit most, having higher yielding lands and cultivating internationally competitive crops. Another interesting finding of their household level analysis is an increase in agricultural production, despite a decrease in the agricultural price index. Farmers respond to the changes in relative prices induced by the WTO by shifting to more competitive activities (livestock, fish, vegetables and rice), resulting in a net increase in agricultural production.

These two studies show that a disaggregated analysis of the impact of trade reform yields insights that cannot be attained from national level studies. Our objective in this paper is to contribute a village level perspective on trade reform in China. Adjustment responses of different household types and within-village interactions are central to this analysis. This study complements earlier studies by zooming in on the differential impact of trade liberalization on households within a village. A new methodology that accounts for family-farm production specifics in a village-economy setting gives us a unique perspective on the impact of trade reform. Going beyond the household level study of Huang et al. (2003) we account in addition for the impact of farm income on rural household consumption. We furthermore account for the impact of rural-urban migration, thus not limiting the analysis to developments in the agricultural sector.

In this study we combine a macro level analysis of trade reform, with a village level general equilibrium model of a rice-producing village in Jiangxi Province. To be able to combine the macro and village level analysis of trade reform, we need to ascertain how trade reform affects households. Prices and labor demand form the key transmission mechanisms through which macro level trade reform affects rural households (Winters, 2002). We therefore focus on changes in prices for agricultural inputs and outputs, and on the increased demand for labor by labor-intensive sectors in which China has a comparative advantage.

Our analyses of further trade reform builds on a baseline that encompasses China's recent WTO accession, phasing out of export quota for textiles under the Agreement on Textiles and Clothing. We use the GTAP model to generate macro-level impacts of further reform under a WTO -Doha round and feed these into the village-level model.

The village equilibrium model incorporates farm-household models, allowing us to analyze the impact of changes in farm production, off-farm employment and household consumption, as well as the interactions among these three components of household decisions. Since households differ in their 
endowments and access to off-farm employment, household response to changes in the socioeconomic environment differ.

Analyzing the impact of changing in agricultural input and output prices we find an increased village supply of rice and other livestock, which corresponds with the findings of national level studies and with the results of the household analysis in Huang et al. (2003). This increased supply of rice, however, is the net result of two household groups increasing rice production, and two household groups reducing rice production. Analyzing the impact of an increase in outside village employment following trade liberalization, we find it matters whether economic growth is limited to the coastal areas or spread more evenly throughout the country because of differential access to outside province migration. The net impact of an evenly spreads increase in employment on supply response is a decrease in rice supply, caused by an increasing scarcity of labor. Again we find diverging household response, with some households increasing rice production due to lower costs of animal traction rented within the village. The combined impact of price and employment changes following trade liberalization is a decrease in rice supply from the village. In terms of the village supply response, the impact of the increased employment thus dominates the impact of the change in prices.

When analyzing the income effects of trade liberalization we find it matters considerably whether we account for reduced household consumption due to migrants. Ignoring the consumption of migrants, trade liberalization would reduce within-village income inequality; accounting for the consumption impact we find that trade liberalization worsens within-village income distribution.

This paper is structured as follows. We start by providing some background on non-separability of household decisions and how this affects the structure of the village equilibrium model. The second section discusses the data and models used in this study. The third section focuses on the impact of price changes, employment and the combination of these two aspects of trade liberalization on household agricultural production decisions. Section four then analyzes the aggregate village supply response as well as the income and welfare impact of trade liberalization. Section five concludes.

\section{A household perspective on general equilibrium modeling}

As illustrated above, a disaggregated perspective can lead to new insights in the impact of trade reform. Analyzing the household level impact of trade reform, the study of Huang et al. (2003) comes closest to the approach taken in this study. Due to data limitations their analysis is limited to analyzing changes in agricultural production, ignoring both changes in household consumption decisions and off-farm employment. Separating farm production decisions from household consumption decisions is standard in general equilibrium models, both macro as well as existing village general equilibrium models. Ignoring the interdependency of household production and consumption decisions, however, can be misleading when market imperfections render these two aspects of household decisions nonseparable.

Nonseparability of household production and consumption decisions occurs when the effective price of a commodity used both in production and consumption is not exogenous to the household, but is determined endogenously by household demand and supply. In this case decisions at the production 
side will affect demand and supply of the commodity, which affects consumption decisions, and vice versa. Such nonseparability occurs if households are not price-takers in a market, if markets are missing, or if there is a gap between buying and selling prices (Löfgren and Robinson, 1999). The seminal work of de Janvry, Fafchamps and Sadoulet (1991) shows how rational behavior of farmers in combination with market failures may give rise to sluggish or counterintuitive household responses.

To illustrate a number of points regarding nonseparable household models a simple model is postulated. The household is assumed to maximize utility derived from the consumption of an agricultural commodity $C_{a}$ (e.g. a food crop produced by the household) and leisure $C_{l}$. The household faces a production technology producing the food crop $\left(Q_{a}\right)$ with family labor $\left(L_{f}\right)$, hired labor $\left(L_{h}\right)$, and a fixed input $(\bar{q})$. The household may also work off-farm $\left(L_{o}\right)$, but total labor use cannot exceed the family time-endowment $(\bar{T})$. The cash constraint provides a third constraint on utility maximization; goods can only be bought if money is earned. In this simple model without savings and transfers this constraint translates to requiring the inflow of money to equal to the outflow.

This very basic household model can mathematically be described as:

$$
\max _{C_{a}, C_{l}, L_{f}, L_{h}} u\left(C_{a}, C_{l}\right)
$$

utility function

subject to,

$$
\begin{aligned}
& Q_{a}=f\left(L_{f}, L_{h}, \bar{q}\right) \\
& L_{f}+L_{o}+C_{l}=\bar{T} \\
& p Q_{a}+w L_{o}=p C_{a}+w L_{h}
\end{aligned}
$$

production function

time constraint

cash constraint

where, in addition to the variables defined before, $p$ denotes the price of the food crop and $w$ the wage rate. The three constraints may be collapsed into a single full income constraint, by substituting the production function and time constraint in the cash constraint, and rearranging:

$$
p\left[f\left(L_{f}, L_{h}, \bar{q}\right)-C_{a}\right]=w\left[L_{h}-\left(\bar{T}-L_{f}-C_{l}\right)\right] \quad \text { full income constraint }
$$

Maximization of the utility function (1) subject to the full income constraint (2) yields input demand, output supply and consumption decisions of the household.

In the mathematical description the interaction between production and consumption decisions is not immediately obvious. Due to its simplicity the model can also be solved graphically, which does allow a direct view on (non-)separability of household decisions (Taylor and Adelman, 2003). The mathematical description assumes perfect markets for food and labor, which can be purchased and sold at fixed prices $p$ and $w$. No distinction is made between own produced and purchased food, nor between family and hired labor. Due to the fixed prices, production and consumption decisions can be separated, as is illustrated in Figure 1.

The household faces a trade-off between producing food crop and leisure, depicted by the production possibility frontier (PPF). The optimal production level with perfect markets $\left(\mathrm{PM}^{\mathrm{P}}\right)$ is at the point where the slope of the PPF equals the price-ratio between labor and food. Optimal consumption with perfect markets $\left(\mathrm{PM}^{\mathrm{C}}\right)$ is at the point where the marginal rate of substitution equals the price ratio. These are standard micro-economic results from producer and consumer theory, reflecting the 
neoclassical nature of the model. The graphical representation illustrates that first the production problem is solved (moving the line representing the price-ratio until it just touches the PPF), after which the solution to the consumption problem is found (finding the highest indifference curve (I) still touching the relative price line).

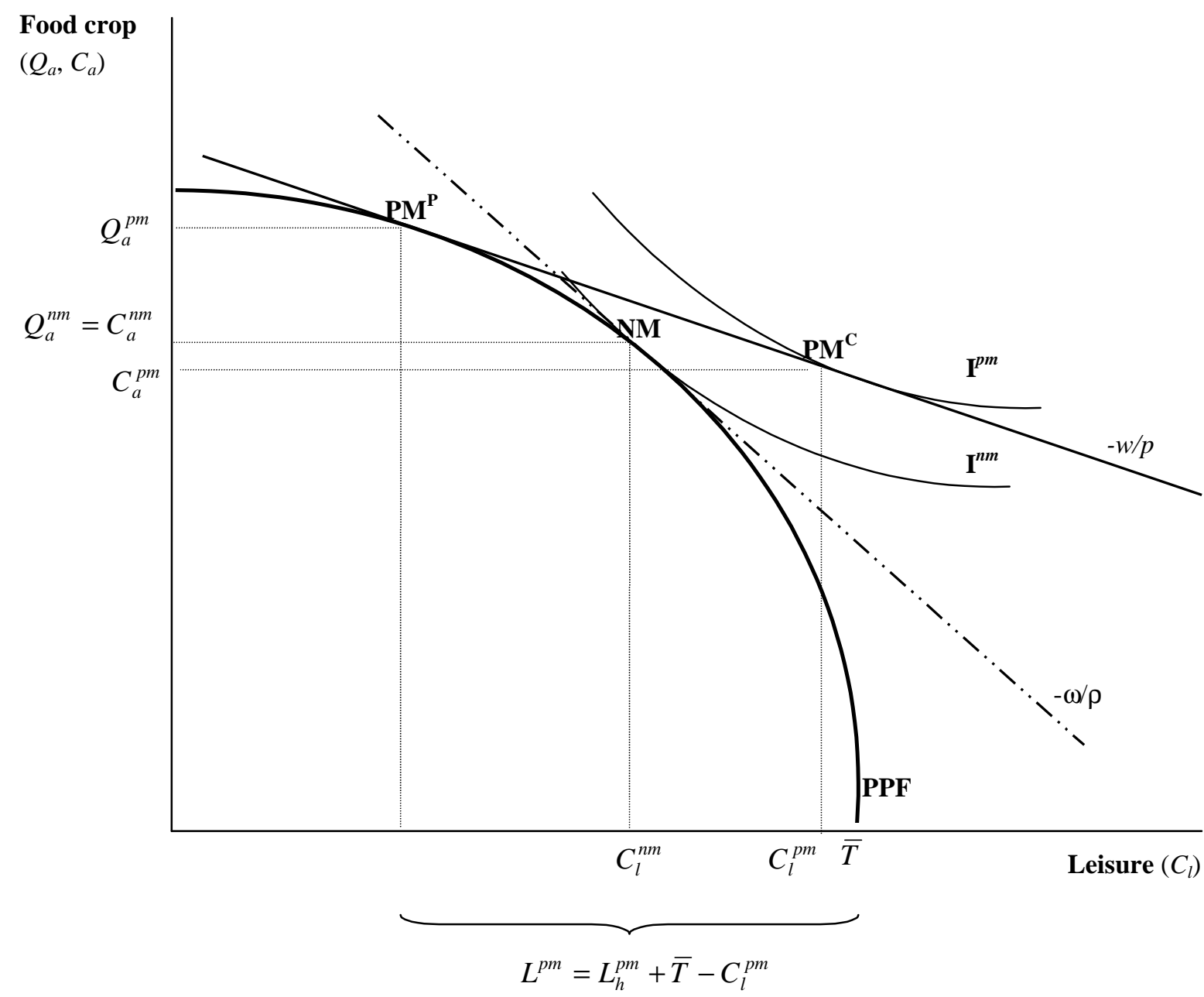

Source: adapted from Taylor and Adelman (2003)

Figure 1: $\quad$ Household production and consumption decisions with perfect markets $(\mathrm{pm})$ and no markets $(\mathrm{nm})$ for food and labor

The opposite extreme from perfect markets is an absence of all markets. In this case prices are no longer given, but determined by the interplay of production and consumption decisions. In terms of Figure 1 this implies finding the point (NM) where the indifference curve $\mathrm{I}^{\mathrm{nm}}$ touches upon the PPF. In this point the household consumes all the output it produces, and the amount of labor it uses equals the time-constraint minus leisure. In this case the prices of food and labor are no longer exogenous. Instead they are endogenous shadow prices $(\omega$ and $\rho$ ) that cannot be observed in the absence of trade 
with the outside world. The graphical representation illustrates the nonseparability: the optimal point is now found by simultaneously dealing with consumption decisions represented by the indifference curve and production decisions represented by the production possibility frontier.

This basic household model and its graphical solution illustrate a number of points that are essential to farm household modeling. First, standard economic rules for production and consumption remain valid. Differences with a separate analysis of production and consumption decisions occur because of endogenous prices, not because of different behavior by the household. This result implies that standard approaches to modeling production and consumption decisions may be also followed. Although the analytical framework remains the same, endogenous household prices complicate the development of an applied model. The household shadow prices are an analytical construct and thus cannot be directly observed. This complicates the estimation of demand and supply functions for nonseparable household models.

Second, household models tend to generate ambiguous result and easily become analytically intractable. Ambiguous results may already occur with perfect markets. In the graphical example given above, assume that prices for food increase The price-ratio line will flatten and the point of tangency to the PPF will be at a higher level of food production. The increase in production and prices increases income of the household. The household will be able to shift to a higher indifference curve and increases its food consumption. The increase in food consumption may outweigh the increase in food production, depending on the preferences of the household. The food price increase then does not lead to an unequivocal increase in marketed surplus. If an analytical solution of the household model can be derived, it will generally be difficult to sign because of counteracting effects on the production and consumption sides of the household. In models with multiple missing markets interdependencies between variables will prevent derivation of an analytical solution. Problems in deriving an analytical solution and ambiguous results of analytical solutions, if they can be derived, are important reasons for the development of quantitative household models.

Third, accounting for different levels of market integration of households has clear policy relevance. As the graphical solution in Figure 1 illustrates, integration in markets increases the welfare of the household. Apart from the welfare implications for the household, interaction between producer and consumer decisions may result in unexpected results. For example, if the objective of a food price policy is to increase the marketed surplus, limited market integration of households may yield adverse results. Household models help in understanding counterintuitive response to policy changes, as well as identifying possible complementary policies that promote the desired response.

Nonseparability has become an important feature of household models, but is absent in existing general equilibrium models. A study by Löfgren and Robinson (1999) provides a stylized application of including farm-household models in a general equilibrium model, but this approach has not yet been implemented in an empirical analysis.

Given the recent transformations in China, markets are still developing and imperfections can be expected to be abound. Studies of factors influencing migration decisions (Hare, 1999; Murphy, 2000; Rozelle et al., 1999a; Rozelle et al., 1999b) and of patterns in inequality (Benjamin and Brandt, 1999), refer to imperfect land, labor and credit markets as being relevant in the Chinese context. Such 
a partial integration in markets may give rise to nonseparability of household decisions, or may create (thin) local markets through which household decisions affect each other.

If households interact with each other in local village markets, and these markets are not integrated with markets outside of the village, local general equilibrium effects occur. Studies of market integration in China find villages to be integrated in markets for major outputs (Huang et al., 2003) and for fertilizer (Qiao et al., 2003). While villages may thus be assumed to be integrated in agricultural input and output markets, integration of factor markets is limited. Labor markets are highly segmented (Gilbert and Wahl, 2003), resulting in a rural labor surplus (Cook, 1999). Village labor markets, however, can be expected to be limited. Due to the collective ownership of land, all households have access to land. Lacking landless households and generally having similar agricultural production patterns, there is little scope for local labor markets.

While limiting the prospect for local labor markets, collective ownership of land results in village land markets. Land rights remain ambiguous, in spite of land tenure reforms that have granted household user rights for 30 years, and recently were changed to permit inheritance (Huang and Rozelle, 2004). Land is allocated on the basis of demographic criteria, and readjustments occur to adjust for changes in household size, despite formal household user rights. The result is an ambiguous land tenure situation (Ho, 2001) in which households have an incentive to keep their land cultivated to avoid loosing it during a next readjustment. Households that migrate to urban areas therefore rent their land to other households, to maintain their claim to the land in case they are unable to secure a living in the urban areas. Given the ambiguity of land tenure, land rental markets are restricted to villagers, resulting in local land markets.

Village interactions may also arise through informal credit markets. Government intervention in the formal banking sector remains strong. Regulated interest rates are well-below market clearing levels, while soft loans to state enterprises seize a large share of available funds. Rural households are thus rationed out of credit markets. In the late 1980s, rural cooperative funds developed, targeted at rural households. These funds proofed too successful competitors of existing rural credit cooperatives and were dissolved in 1999 (Park et al., 2003). As a result of the lack of formal credit options, household have to rely on loans from friends and relatives, generating local informal credit markets.

Despite the integration in agricultural input and output markets, local markets for land and capital are thus expected to exist, and imperfect labor markets are expected to result in nonseparability of household production and consumption decisions. In this study we therefore use a village level general equilibrium model to account for the interactions among households in local markets, while paying due attention to nonseparability of household decisions.

Taylor and Adelman (1996) pioneered the use of general equilibrium models at village level. Their model closely follows the structure of macro level models, for example by modeling production at sector level, which misses the impact of nonseparability of household decisions. We take a different approach to village modeling, placing differences in household response due to nonseparability at the center of the model. This household perspective on general equilibrium modeling results in a different model structure than used in macro level general equilibrium models and in existing village level models. We model production activities as being household-specific. This allows for idiosyncratic household response consistent with nonseparability of production and consumption decisions. A 
second major difference is the nesting structure used for modeling production decisions. For each activity the structure is calibrated on the household survey data ${ }^{1}$. As a result we have household specific production functions, capturing differences in household access to inputs ${ }^{2}$.

By placing households at the center of the model, the village model used in this study is able to capture differences in production decisions reflecting differences in access to the inputs, interactions between household production and consumption decisions, and interactions among different households within a village economy.

\section{Models and data}

\section{$2.1 \quad$ Macro level analysis}

The macro economic analyses are performed using the GTAP model, with some important modifications to the version 5 database. Van Tongeren and Huang (2004) describes the changes made and the baseline simulation which is the reference for the scenarios used in the present study. Specifically, we have updated policy information on China from the original version 5 GTAP database to include recent changes in domestic policies and changes in border policies. In addition we have adjusted the Chinese input-output table to incorporate microdata information on primary factor shares. We also made adjustments to the data on livestock production and - consumption. Using macro-economic information, and incorporating known imminent policy changes, we project the database forward in time to the year 2010 and beyond. The policy changes along the baseline include the full implementation of China's WTO accession and the phasing out of export quota under the Agreement on Textiles and Clothing. This baseline is the reference for simulations to assess the effects of further trade liberalization under the WTO Doha round.

Our experiment reduces multilaterally the support to agriculture grouped under the three classical pillars, market access, export competition and domestic support, and it reduces border distortions in non-agricultural sectors. The simulation for agriculture follows closely the original modalities proposal tabled in 2002 by the European Commission (European Commission, 2002). This proposal contained a certain asymmetry between the treatment of OECD countries and developing countries. Specifically, we model a reduction of import tariffs by $-36 \%$ for trade amongst OECD countries and total elimination of import barriers against LDCs, while LDCs themselves are not reducing their import barriers. In the area of export competition, we reduce the value of subsidies by $-45 \%$ in OECD countries only, and eliminate fully the export subsidies on wheat and oilseeds. In the area of domestic support, the AMS ceiling is lowered by $-55 \%$, but the blue box payments are maintained. All reductions are made from the final Uruguay Round commitments. For Non-agricultural Market access, we apply a straight $-50 \%$ reduction of applied rates. It should be noted that this simulation is illustrative for the possible effects of a successful round. Within the spectrum of proposals offered prior to the ministerial meeting in Cancun, September 2003, the EC proposal is rather conservative. An assessment of the more far-reaching proposals tabled by the CAIRNS group and the US are discussed in Van Tongeren and van Meijl (2004).

1 This calibration also rejected the commonly assumed separability of factors and intermediate inputs, and this assumption was therefore dropped in the village equilibrium model. 
The main findings for China from the Doha simulation can be summarized as follows. Processed food, labor intensive horticulture and textiles obtain the highest production gain. In these sectors, China has already a comparative advantage, and exports are an important part of total demand. For processed food tariffs cuts are relatively high and exports are important. We observe a modest output growth in rice. For textiles tariff cuts are modest but exports are very important, so export growth leads to growth production. We also observe an increase in livestock output.

While exports are estimated to grow in some products, the further reduction of remaining import barriers also enables China to import more products. Imports in such commodities as coarse grains, sugar, cotton, dairy and intensive livestock products are expected to rise.

Table 1: Shocks administered to village model (\% change with respect to base)

\begin{tabular}{|c|c|c|c|c|}
\hline & & Price changes & Employment & $\begin{array}{c}\text { Trade } \\
\text { liberalization }\end{array}$ \\
\hline \multirow[t]{6}{*}{ Agricultural outputs } & One season rice & 2 & - & 2 \\
\hline & Two season rice & 2 & - & 2 \\
\hline & Other crops & 2 & - & 2 \\
\hline & Cattle & 2 & - & 2 \\
\hline & Pigs & 2 & - & 2 \\
\hline & Other livestock & 2 & - & 2 \\
\hline \multirow[t]{6}{*}{ Agricultural inputs } & Fertilizer & 0 & - & 0 \\
\hline & Herbicides & 0 & - & 0 \\
\hline & Pesticides & 0 & - & 0 \\
\hline & Seed & 2 & - & 2 \\
\hline & Purchased feed & 2 & - & 2 \\
\hline & Other inputs & 1 & - & 1 \\
\hline \multirow[t]{5}{*}{ Consumption goods } & Food & 2 & - & 2 \\
\hline & Processed food & 2 & - & 2 \\
\hline & Nonfood & 1 & - & 1 \\
\hline & Durables & 1 & - & 1 \\
\hline & Other expenditures & 1 & - & 1 \\
\hline \multirow[t]{3}{*}{ Wages } & Non-agricultural employment & - & 3 & 3 \\
\hline & Migration, inside province & - & 3 & 3 \\
\hline & Migration, outside province & - & 3 & 3 \\
\hline \multirow[t]{3}{*}{ Outside employment } & Non-agricultural employment & - & 9 & 9 \\
\hline & Migration, inside province & - & 9 & 9 \\
\hline & Migration, outside province & - & 7 & 7 \\
\hline
\end{tabular}

It can be concluded that China can gain a lot from a new WTO round, but most from liberalization in manufacturing. Around $60 \%$ of the potential income gains can be attributed to improved market access for manufacturing goods into OECD countries. Labor intensive manufacturing and food processing industries have the potential to absorb labor and generate incomes in activities outside

${ }^{2}$ Detailed description of the village equilibrium model and calibration procedures can be obtained from the 
primary agriculture. Expanding labor intensive industries in rural areas may be part of a rural development strategy.

The simulation is performed relative to the year 2010 baseline, and yields amongst other things changes in market prices for key commodities in China, and changes in manufacturing labor demand. These results are fed into the village CGE model. Table 1 summarizes the shocks administered to the village model.

\subsection{Linking the macro results to the village model}

To link the macro analysis to the village model, we follow the conceptual framework of Winters (2002), and focus on prices and labor demand. Studies of market integration of three main staple crops and fertilizer (Huang et al., 2003; Qiao et al., 2003) show integrated regional and national markets, with village level prices responding to changes at national level. These integrated commodity markets allow us to translate relative price changes derived from the macro level analysis to the village level. As in Huang et al. (2003) we use a price transmission coefficient of 0.75 to link macro national level price changes to village level price changes, for commodities that are traded outside the village. This implies that a 1 percent change in the national price is modeled as resulting a 0.75 percent change in village level prices. A less than unitary transmission coefficient reflects existing frictions in domestic trade in China. These frictions are expected the persist in the future, given the findings in Poncet (2003), of a disintegration of domestic markets alongside the continuing integration of China in international markets.

In addition to the transmission of price changes, we analyze the impact of changes in employment opportunities. Studies of trade liberalization find an expansion of labor-intensive sectors in which China has a comparative advantage. We thus need to link an aggregate expansion of employment to village level changes in outside village employment. Lacking data to quantify the link between national level changes in employment and household decisions, we assume percentages changes in aggregate labor demand to be completely transmitted to the village. Percentages changes in outside village employment are thus set equal to changes in aggregate labor demand. Such a one-on-one relation between national level employment and off-farm activities of the households in the case study village seems justified given the findings in Diao et al. (2003). Comparing the change in rural-urban migration across regions following WTO accession, they find the fastest increase in rural-urban migration in the central provinces. The case study village is located in Jiangxi, one of these central provinces, and migration outside of the province plays an important role in the village economy, justifying the assumption of a complete transmission of the demand for labor to the village level.

\subsection{The case study village}

The case-study village has been selected to be representative of rice producing villages in the plain areas of Jiangxi Province, one of the poorer provinces in China. Data on production and consumption of 168 households were collected for 2000, using standard household questionnaires with questions

authors. 
on source and destination of commodities added to allow construction of a village SAM. These surveyed households account for about a quarter of the village population, totaling 729 households.

Differences among households are at the center of our village equilibrium model. Four groups of households are distinguished, using ownership of draught power (cattle or tractor) and access to outside province employment as grouping criteria. The resulting groups represent households with differential capacity for earning a living from agriculture and from (transitory) migration to coastal cities.

Table 2 presents the activities of each household type in terms of contribution to value-added. For all household types off-farm employment contributes a significant share of income, but there exist important differences in the nature of non agricultural income sources. Comparing the two household groups lacking a link outside the province, we find households lacking draught power oriented more towards local off-farm employment, with agricultural activities contributing about 60 percent to valued-added. The households with draught power obtain about 70 percent of value-added from agriculture, which is similar to the importance of agriculture for the other household group owning draught power. The household group with access to migration but lacking draught power derives about 40 percent of value-added from outside province migration, and only derives about 45 percent of value-added from agricultural activities. Differential access to agricultural and migration opportunities is thus reflected in the composition of to value-added.

Table 2: Activity composition (percentage of value-added)

\begin{tabular}{|c|c|c|c|c|c|c|}
\hline & \multirow{2}{*}{$\begin{array}{l}\text { Link outside province: } \\
\text { Owning draught power: }\end{array}$} & \multicolumn{2}{|c|}{ No link } & \multicolumn{2}{|c|}{ Link } & \multirow[t]{2}{*}{ Village } \\
\hline & & No & Yes & $\mathrm{No}$ & Yes & \\
\hline & $N=$ & 78 & 100 & 256 & 295 & 729 \\
\hline \multirow[t]{6}{*}{ Agriculture } & One season rice & 9.4 & 10.8 & 8.2 & 10.5 & 9.5 \\
\hline & Two season rice & 28.5 & 28.2 & 18.6 & 27.1 & 23.9 \\
\hline & Other crops & 21.2 & 24.7 & 18.4 & 22.4 & 20.9 \\
\hline & Cattle & - & 7.5 & - & 8.1 & 4.1 \\
\hline & Pigs & 0.1 & 0.1 & 0.2 & 0.4 & 0.3 \\
\hline & Other livestock & 0.1 & 0.1 & 0.0 & 0.0 & 0.0 \\
\hline \multirow[t]{2}{*}{ Village employment } & Agricultural labor & 1.3 & 2.2 & - & 0.1 & 0.4 \\
\hline & Local business & 19.4 & 13.5 & 2.4 & 2.7 & 5.2 \\
\hline Outside village & Outside employment & 18.0 & 12.9 & 9.1 & 5.4 & 8.9 \\
\hline \multirow[t]{3}{*}{ Migration } & Inside province & 2.1 & - & 4.2 & 0.9 & 2.3 \\
\hline & Outside province & - & - & 38.8 & 22.3 & 24.6 \\
\hline & & 100 & 100 & 100 & 100 & 100 \\
\hline
\end{tabular}

Note: '- indicates that the household is not involved in this activity

Differences in activities result in differences in income patterns across the four household groups. Table 3 presents income per adult consumer equivalent ${ }^{3}$ to allow a direct comparison across

\footnotetext{
${ }^{3}$ Adult equivalent instead of per capita consumption is used to account for differences in consumption between males and females and between age groups. Lacking survey data, conversion factors were taken from detailed
} 
households. The first thing to note is that the household group with an outside link and draught power has the highest income per adult consumer equivalent. This is in line with the assumptions made when grouping households in terms of opportunities for earning agricultural and nonagricultural income. The two household groups without an outside link have similar incomes.

Table 3: Sources of household full income (percentage of total income) and total income (yuan)

\begin{tabular}{|c|c|c|c|c|c|c|}
\hline & \multirow{2}{*}{$\begin{array}{l}\text { Link outside province: } \\
\text { Owning draught power: }\end{array}$} & \multicolumn{2}{|c|}{ No link } & \multicolumn{2}{|c|}{ Link } & \multirow[t]{2}{*}{ Village } \\
\hline & & No & Yes & No & Yes & \\
\hline \multirow[t]{2}{*}{ Labor } & shadow wage income & 57.4 & 52.8 & 52.6 & 62.1 & 57.4 \\
\hline & above shadow wage income & 17.5 & 12.3 & 23.3 & 6.0 & 13.5 \\
\hline \multirow[t]{3}{*}{ Land } & irrigated land shadow income & 12.4 & 13.3 & 12.8 & 11.4 & 12.1 \\
\hline & irrigated land above shadow income & 4.8 & 6.5 & 1.4 & 4.5 & 3.7 \\
\hline & non-irrigated land & 7.3 & 7.9 & 7.7 & 6.6 & 7.2 \\
\hline \multirow[t]{2}{*}{ Capital } & Cattle & - & 3.3 & - & 3.1 & 1.8 \\
\hline & Tractor & - & 1.6 & - & 0.8 & 0.6 \\
\hline \multirow[t]{2}{*}{ Transfer } & within village transfers & 0.6 & 0.3 & 0.0 & 0.5 & 0.3 \\
\hline & receipts from outside village & 0.0 & 1.9 & 2.2 & 5.0 & 3.3 \\
\hline \multicolumn{2}{|c|}{ Income/adult consumer equivalent ( 1,000 yuan) } & 4.4 & 4.3 & 5.0 & 5.5 & 5.0 \\
\hline
\end{tabular}

Note: '-" indicates that the household does not receive income from this source

Specific features of the village SAM and equilibrium model appear in Table 3, in splitting income from labor and irrigated land between shadow income ${ }^{4}$ and above shadow income. The household survey data reveal imperfect labor and land markets. Households are involved in a variety of off-farm activities with different wages. These wages are well above the estimated shadow wage, indicating restricted access to off-farm employment and suggesting a situation of labor surplus at the local level. This does not come unexpected, given the high population density in China and similar findings in a study by Bowlus (2003). In the SAM and village equilibrium model the demand-constrained labor market is accounted for by valuing labor against household-specific shadow wages, estimated using the household survey data. In case of off-farm activities, labor then earns a revenue above the shadow wage which is tracked in a separate account of the SAM.

There is trade in irrigated land (paddy fields), with all four household groups renting in land. Dealing with a village level analysis we would expect the land market to balance. In total, however, households rent in an amount of irrigated land equal to about a third of their contracted land, that is not supplied by surveyed households. When conducting the survey using an official list obtained from the village administration, a number of the randomly selected households were found to have permanently left the village. These were replaced with households of which at least some members

consumption data of a study in Bangladesh (Zeller et al., 2001). In addition to differences in age and gender, consumer equivalents were corrected for the length of absence of household members due to migration.

${ }^{4}$ Nonseparability results in household-specific shadow prices balancing households' demand and supply that cannot be observed. We therefore estimated a production function, explaining the total value of household output by labor, land, manure, feed and external inputs. Based on the estimated production function we computed for each household in the sample the household-specific shadow prices for household non-tradables as the marginal value product of each input. Averaging over the households constituting a household group renders a shadow price for each household nontradable that differs across household groups. These shadow prices are used in constructing the SAM and in calibrating the village equilibrium model. 
were still living in the village, resulting in a biased sample. Lacking households that have moved to the cities, our sample misses the supply of land by households that have moved to the cities. As discussed in Section 1, the combination of collective ownership with household user rights has resulted in an ambiguous land tenure system. This applies to the case study village, were according to the survey data, land reallocations are still occurring. Migrated households thus have an incentive in keeping their land cultivated by renting it to other households.

Given the ambiguous land tenure system, assuming a perfect land market seems a far stretch from the pattern observed in the data. We therefore estimated a shadow price for irrigated land, which on average was about 1.5 times the rent paid for the land. This result fits a distorted land market, where insecure land tenure prevents households leaving the village from obtaining a rent reflecting the true production value of the land. At the demand side, this implies that households can rent land for a price well below the productive value of the land. In the SAM and village equilibrium model this is accounted for by having all household groups earning a profit on the land rented in, which is equal to the difference between the estimated valued of the land and the rent paid. The amount of rented land is kept fixed in the village model, since additional supply is assumed to be associated with the migration of a complete household, which is beyond the scope of this study.

A last remark on the village SAM is the lack of data for modeling capital flows in the village. The SAM shows that the household group most involved in migration is a net supplier of money for the other three groups of households. Although the survey contains some data on the conditions on which money is provided, insufficient information is available to model a village capital market. In the analysis money flows among households are therefore assumed fixed at the level observed in the SAM. This excludes one way through which income from migration could be transmitted through village linkages, thus potentially underestimating the village-wide impact of migration.

To summarize the discussion so far, we are analyzing the response of four different types of households, distinguished on the basis of their access to agricultural income and income from outside province migration. Analyzing sources of income pointed to imperfect labor and land markets. These are accommodated by estimating household-specific shadow prices, introducing profits earned on offfarm employment and renting of land, and by modeling household production and consumption decisions as nonseparable.

\subsection{The village equilibrium model}

Despite introducing nonseparability of household production and consumption decisions, the mathematical structure of the model closely resembles macro level general equilibrium models. Consumption decisions are modeled through a linear expenditure system, while production is modeled by nested CES functions. Because of the level of detail in the village model, we do not observe twoway flows of commodities with the outside world. Households consume farm output, but do not purchase these goods from outside the village, nor from other households in the village. Household sales to outside village markets are thus equal to total production, minus household consumption.

Off-farm employment options were found to be restricted, resulting in wages exceeding the shadow price of labor. This is handled in the village equilibrium model by fixing the levels of outside village employment and having households earn a profit above labor costs on off-farm activities. Levels of 
village employment (agricultural and nonagricultural) cannot be fixed, although for these activities wages also exceed shadow wages. Demand for agricultural labor is therefore assumed to be demanddriven, with prices being fixed ${ }^{5}$. Demand for village non-agricultural labor is linked to local business activities, discussed below.

Village markets exist for traction by draught animals or tractors, and for locally produced consumption goods. Of these village markets, only animal traction has an endogenous village price in the model. The SAM indicates that only limited use is made of the tractors. This under-utilization of available tractors is therefore modeled through fixed prices for tractor services, and tractor endowments adjusting to demand ('unemployment' closure).

Due to lack of data on other inputs, local business activities use only labor (village non-agricultural labor), yielding a return that exceeds the shadow wages. All households are involved in local business activities and all purchase locally produced goods. This reflects a heterogeneity in goods not captured by the aggregates used in the SAM and village model. Because of lack of data we fix village prices of local goods to deal with the gap between product prices and costs of labor. Assuming fixed prices seems justified since prices of village produced goods are common knowledge, while shadow wages cannot be observed. Given the unobservable character of shadow wages, it seems unlikely that a change in labor costs will be reflected by a changed village price. A second reason for fixing prices of local business activities is the absence of a peak season. Production can therefore be shifted to times when little labor is needed in agriculture, limiting the need to increase the price when shadow wages increase.

For all demand-driven activities (local consumption goods, hired agricultural labor, tractor services), market equilibrium is established by allocating demand to suppliers based on the market shares observed in the SAM.

Summarizing, the village equilibrium model resembles macro level general equilibrium models by the way in which consumption and production are modeled. A major difference with macro and existing village level models is the household-specific production, which is affected by household consumption decisions through endogenous household shadow. Lack of data resulted in most village markets to be modeled as demand-driven. The only exception is the village market for animal traction, which is balanced through an endogenous village price. Household production and consumption decisions are calibrated on the household survey data, resulting in household-specific demand and supply functions.

\section{Household production response to trade liberalization}

Following the analytical framework of Winters (2002) we analyze two pathways through which trade affects households: prices and employment. We first separately analyze the impact on household response these two aspects of trade liberalization, followed by an assessment of their combined effect.

\footnotetext{
${ }^{5}$ Agricultural wages are a multitude of shadow wages. Households are therefore always willing to supply agricultural labor.
} 


\subsection{Household level impact of price changes}

Trade liberalization increases prices of all agricultural outputs and some inputs. In terms of crop production, all household groups show a limited response in other crop production, and a significant change in rice production (Table 4). This difference in response is due to the fixed amount of land used in other crops. This is the only activity which uses non-irrigated land, which is a household nontradable. This fixed input limits the adjustment possibilities, although the change in shadow price of non-irrigated land (Table 5) indicates that households are adjusting to the price changes, despite their limited production response. This provides a classic illustration of the point made in de Janvry et al. (1991) that, although market imperfections may cause sluggish production response, households accommodate price changes by making internal adjustments.

Table 4: Household production response to price shocks (\% change compared to base)

\begin{tabular}{llrrrrr}
\hline & \multicolumn{2}{c}{ Link outside province: } & \multicolumn{2}{c}{ No link } & & \multicolumn{2}{c}{ Link } \\
\cline { 3 - 4 } \cline { 6 - 7 } Cwning draught power: & No & Yes & & No & Yes \\
\hline \multirow{6}{*}{ Lrops } & One season rice & 3 & 84 & & -12 & -22 \\
& Two season rice & 0 & -35 & & 6 & 11 \\
& Other crops & 0 & -1 & & 0 & 0 \\
& Pig production & -11 & -84 & & -1 & -7 \\
& Other livestock & 148 & 2420 & & 16 & 104 \\
\hline
\end{tabular}

In the case of rice, land can be allocated between two different types of rice production. One season rice consists of a single crop, while two season rice is a double-cropping system. Consisting of two crops, the latter uses more inputs, for example for transplanting which is a rather labor intensive activity. This difference in labor requirements accounts for the difference between households with no link outside the province (moving to one season rice) and those with a link outside the province (moving to two season rice).The exogenous increase in rice prices raises shadow wages, which are based on the value of their marginal product. Ceteris paribus, the increase in the price of rice makes two season rice more attractive than one season rice, since it has a higher yield. This higher yield, however, is obtained through a more intensive production. Expanding two season rice thus requires more labor, increasing shadow wages. For the two household groups lacking an outside link, this increase in production costs counterweighs the exogenous increase in output prices.

Table 5: Household-specific price response to price shocks for traded commodities (\% change compared to base)

\begin{tabular}{|c|c|c|c|c|c|}
\hline & \multirow{2}{*}{$\begin{array}{l}\text { Link outside province: } \\
\text { Owning draught power: }\end{array}$} & \multicolumn{2}{|c|}{ No link } & \multicolumn{2}{|c|}{ Link } \\
\hline & & $\mathrm{No}$ & Yes & $N o$ & Yes \\
\hline \multirow[t]{3}{*}{ Agricultural output } & Two season rice & 2.0 & 2.2 & 2.0 & 2.0 \\
\hline & Pig production & 2.0 & 4.6 & 2.0 & 2.0 \\
\hline & Feed & 3.4 & 9.4 & 2.4 & 3.4 \\
\hline \multirow{3}{*}{$\begin{array}{l}\text { Endowments } \\
\text { (shadow wages and } \\
\text { rental rates) }\end{array}$} & Family labor & 2.7 & 7.2 & 1.2 & 4.3 \\
\hline & Irrigated land & 2.6 & 5.0 & 2.0 & 2.7 \\
\hline & Non-irrigated land & 1.0 & -2.4 & 2.4 & 0.2 \\
\hline
\end{tabular}


As the more moderate shadow wage increases in Table 5 suggests, the two household groups with an outside link have a larger labor endowment, even after accounting for the absence of household members due to migration. As a result their shadow wage increases less, despite shifting to more intensive rice cultivation. The shadow wage increase of 7.2 percent for the household with no outside link but owning draught power, reflects that this household type has the smallest labor endowment, explaining its shift to one season rice.

If we then turn to the livestock activities, we find pig production to be reduced, while other livestock production increases. These different responses have to do with differences in production technology. Pig production is largely based on farm-produced feed, mainly consisting of crop-residues that are relatively fixed in supply. An increase in pig production will raise the price of feed, being a household nontradable, making it a less attractive activity. Other livestock uses mainly purchased feed and a limited amount of labor. The feed is purchased outside the village against a fixed price, and other livestock production can thus be expanded as long as cash and labor are available.

The household owing draught power and lacking an outside link, shows a dramatic expansion in other livestock production. This expansion is less dramatic than it seems at first sight because of the small size of this activity in the SAM, accounting for only 0.1 percent of value added. The attraction of other livestock for this household is that it uses much more purchased feed, as opposed to farmproduced feed, than the other household types. As a result the response of this household is less affected by the increasing costs of farm-produced feed, resulting in its strong production response.

Households consume part of their own production. With the linear expenditure system, consumption of farm output is inelastic. The change in production is thus not matched by a change in consumption, resulting in a stronger change in marketed surplus than in produced output (Table 6). The strong production response of the household owning draught power and lacking an outside link, is reflected by its withdrawal from the market for two season rice and pigs. For these two activities this household limits production to its own consumption needs. Not being active in the market, the market price is no longer relevant. Instead two season rice and pigs have a household-specific shadow price which exceeds the market price that still holds for the other three household groups (see Table 5).

Table 6: Household marketed surplus response to price shocks (\% change compared to base)

\begin{tabular}{llrrrrr}
\hline & \multicolumn{2}{c}{ Link outside province: } & \multicolumn{2}{c}{ No link } & & \multicolumn{2}{c}{ Link } \\
\cline { 7 - 8 } \cline { 6 - 7 } Owning draught power: & No & & Yes & & No & Yes \\
\hline \multirow{5}{*}{ Livestock } & One season rice & 12 & 119 & & -24 & -43 \\
& Two season rice & -4 & -100 & & 19 & 39 \\
& Other crops & -9 & -12 & & 1 & -5 \\
& Pig production & -11 & -100 & & -2 & -10 \\
& Other livestock & 332 & 5123 & & 62 & 284 \\
\hline
\end{tabular}

The discussion of price changes focused on the impact of changes in agricultural prices. The scenario analyzed also includes an increase in the price of consumption goods. Given nonseparability, this 
price increase may affect household production decisions. The impact of the price of consumer goods on production are found to be minor, and are therefore not discussed further.

We now turn to analyzing the impact of labor demand, providing the second pathway through which trade liberalization affects households. Demand for agricultural labor is determined endogenously by agricultural production decisions, and we therefore focus this section on non-agricultural employment. As discussed in the introduction, economic growth in China has concentrated in the coastal provinces, resulting in an uneven distribution of the benefits of growth. Lacking information to link national level changes to regional changes in non-agricultural sectors, we can only make a crude assessment of the impact of uneven economic development, through a two-step analysis of changes in nonagricultural employment. To capture the concentration of economic growth in the coastal cities, we start by analyzing the impact of an increase in outside province employment.

Only two of the four households groups have access to outside province employment. Comparing the production response between the household groups with and without access to outside province, we find opposite production responses, which is most pronounced for rice (Table 7). Households that have an increased opportunity for outside province migration, move from one season to two season rice, reducing demand for labor which has become more scarce. The households lacking access to outside province migration move in the opposite direction by increasing two season rice production. Since these household are not directly affected by the increased migration opportunities, interactions in local markets cause their response. It turns out that interactions in the village market for animal traction transmit the effects of the increased migration, and therefore mainly affect the household owning draught power. The shift to one season rice by the migration households reduces the demand for animal traction, resulting in a decrease of the price for traction. The two households not involved in migration do not face a increased shadow wage, which combined with the lower costs for traction makes the more intensive two season rice production more attractive.

Table 7: Household production response to increase in outside province migration (\% change)

\begin{tabular}{|c|c|c|c|c|c|}
\hline & \multirow{2}{*}{$\begin{array}{l}\text { Link outside province: } \\
\text { Owning draught power: }\end{array}$} & \multicolumn{2}{|c|}{ No link } & \multicolumn{2}{|c|}{ Link } \\
\hline & & No & Yes & No & Yes \\
\hline \multirow[t]{3}{*}{ Crops } & One season rice & -2 & -22 & 5 & 77 \\
\hline & Two season rice & 1 & 10 & -2 & -34 \\
\hline & Other crops & 0 & 0 & -1 & 0 \\
\hline \multirow[t]{2}{*}{ Livestock } & Pig production & 0 & 0 & 3 & -2 \\
\hline & Other livestock & -5 & -47 & -24 & 93 \\
\hline
\end{tabular}

The reduction in the price of animal traction also reduces cash income of the two household groups owning draught power. For the household group with access to migration, this decrease in cash income is outweighed by an increase in remittances. A net increase in cash remains, which in combination with the higher shadow wage results in an expansion of other livestock production. The household lacking access to migration faces a reduction in the available cash due to the decreased 
incomes from renting animal traction services. This household group also has the most capital intensive other livestock production, resulting in a contraction of this activity.

Only shocking outside province employment thus shows that because of asymmetric access to outside province migration and village interactions, opposing production changes occur. Despite a concentration of economic growth in coastal cities, other regions benefit from trade liberalization as well. Since all household types are involved in off-farm employment, they will all benefit from an increased demand for nonagricultural labor outside the village. An increase in all types of off-farm employment, either inside or outside the province, has a similar impact as found above for the two households with an outside province link (Table 8). Migration outside the province accounts for about 70 percent of their off-farm employment income, and the analysis above about covers the impact of an increase in outside village employment.

Table 8: Household production response to increase in outside village employment (\% change compared to base)

\begin{tabular}{|c|c|c|c|c|c|}
\hline & \multirow{2}{*}{$\begin{array}{l}\text { Link outside province: } \\
\text { Owning draught power: }\end{array}$} & \multicolumn{2}{|c|}{ No link } & \multicolumn{2}{|c|}{ Link } \\
\hline & & No & Yes & No & Yes \\
\hline \multirow[t]{3}{*}{ Crops } & One season rice & -15 & 15 & 8 & 77 \\
\hline & Two season rice & 5 & -6 & -4 & -33 \\
\hline & Other crops & 0 & 0 & -1 & 0 \\
\hline \multirow[t]{2}{*}{ Livestock } & Pig production & 2 & 3 & 4 & -1 \\
\hline & Other livestock & -44 & -47 & -27 & 78 \\
\hline
\end{tabular}

Of the two households lacking an outside province link, the household owning draught animals shows a qualitatively different response in terms of rice production, than when analyzing outside province migration. This household type has a limited involvement in outside village employment (accounting for 12 percent of its value-added), but having the smallest labor endowment its shadow wage does increase when off-farm employment increases. At the same time, the demand for animal traction drops further, due to the twice as strong reduction in two-season rice of the household with an outside link but not owning draught power. An increasing shadow wage combined with a reduction in cash income that is only partly compensated by an increased off-farm income, the household owning draught power but not having access to migration increases one season rice production. This shift reduces demand for labor and cash, that have both become scarcer.

Summarizing, an increase in outside village employment has a differential impact on households groups, depending on their factor endowments and access to different types of off-farm employment. Separately analyzing an increase in migration to coastal provinces shows that the access to employment by two household groups, triggers a strong production response of the households lacking such access. Local markets for animal traction provide the main link through which these changes are transmitted through the village economy. If the increased demand for labor is not concentrated in the coastal cities, all households benefit from an increase in off-farm income. Concentrated versus evenly distributed increase in labor demand qualitatively changes the response of one household type, pointing to a need for a more disaggregated analysis of the impact of trade liberalization. 
Analyzing the two pathways through which trade liberalization affects households resulted in opposing production responses (compare Table 4 and 8). This raises the question what the net impact of these two types of shocks are. Major changes occurred with rice and livestock production, for these activities we therefore indicated whether the increase in agricultural prices or the increase in outside village employment dominates household response. From the entries in Table 9 we can conclude that the dominant aspect of trade liberalization depends on the household type.

Table 9: Household production response to trade liberalization (\% change compared to base) $\left(^{*}\right)$

\begin{tabular}{|c|c|c|c|c|c|}
\hline \multirow{3}{*}{ Crops } & \multirow{3}{*}{$\begin{array}{l}\text { Link outside province: } \\
\text { Owning draught power: } \\
\text { eason rice }\end{array}$} & \multicolumn{2}{|c|}{ No link } & \multicolumn{2}{|c|}{ Link } \\
\hline & & No & Yes & $\mathrm{No}$ & Yes \\
\hline & & $-32(o)$ & 83 (i) & $-5 \quad(a)$ & $78 \quad(o)$ \\
\hline & Two season rice & $11(o)$ & $-34 \quad(i)$ & $4(a)$ & $-33(o)$ \\
\hline & Other crops & -1 & -1 & -1 & -0 \\
\hline \multirow[t]{2}{*}{ Livestock } & Pig production & $-7 \quad(a)$ & $-84 \quad(i)$ & $3(o)$ & (i) \\
\hline & Other livestock & $84 \quad(a)$ & 2398 (i) & $-15(o)$ & 209 \\
\hline
\end{tabular}

Note: $(a)$ means the change in agricultural prices dominates; $(o)$ means the change in outside village employment dominates; (i) means prices and employment have an identical impact in qualitative terms. ${ }^{*}$ ) combined effect of price changes and outside village employment.

In case of the household type owning draught power and lacking a link outside the province, the two aspects of trade liberalization have the same qualitative impact. The total impact is almost identical to the impact of changing agricultural prices, which is due to the limited involvement in off-farm employment of this household type. The other household group owning draught power has a similar pattern of shifts in agricultural production. In this case the impact of outside village employment dominates, which is not surprising since this already accounts for a quarter of its value-added in the base run. Both household groups owning draught power thus shift to one season rice and other livestock production, but this is because of change in agricultural prices for one household type while being due to changes in outside province migration for the other.

The two household groups not owning draught power display an opposite shift in crop production, by moving to two season rice. Both earn a significant share of their value-added from outside village employment. Surprisingly, for the household involved in migration the impact of the increase in employment (accounting for 50 percent of value-added) does not dominate its response. The increase in rice prices combined with the decreased costs of animal traction outweighs its increased shadow wage. The importance of off-farm employment thus does not fully determine which aspect of trade liberalization dominates.

The other household type that does not own draught power earns a smaller part of its income through off-farm employment, and therefore has a more modest increase in its shadow wage (Table 10). For this household type the decreased price of animal traction following an increase in employment outweighs the rise in labor costs, resulting in a shift to two season rice. 


\begin{tabular}{|c|c|c|c|c|c|}
\hline & \multirow{2}{*}{$\begin{array}{l}\text { Link outside province: } \\
\text { Owning draught power: }\end{array}$} & \multicolumn{2}{|c|}{ No link } & \multicolumn{2}{|c|}{ Link } \\
\hline & & $\mathrm{No}$ & Yes & $\mathrm{No}$ & Yes \\
\hline \multirow[t]{2}{*}{ Agricultural output } & Two season rice & 2.0 & 2.2 & 2.0 & 2.1 \\
\hline & Pig production & 2.0 & 4.2 & 2.0 & 2.0 \\
\hline \multirow{4}{*}{$\begin{array}{l}\text { Endowments } \\
\text { (shadow wages and } \\
\text { rental rates) }\end{array}$} & Family labor & 8.8 & 10.3 & 14.3 & 8.9 \\
\hline & Irrigated land & 1.7 & 5.2 & 2.6 & 3.7 \\
\hline & Non-irrigated land & -0.8 & -3.9 & -2.3 & -0.2 \\
\hline & Animal traction services & n.a. & -2.6 & n.a. & -2.6 \\
\hline
\end{tabular}

Three of the households groups increase other livestock production. This activity uses a lot of external inputs and is constraint by the availability of cash needed for purchasing external inputs. The increase in output prices and outside village employment release this cash constraint, resulting in an spectacular percentage increase in other livestock production. Actual marketable amounts are more modest since it only accounts for a fraction of total output in the base run (see below). The household with an outside link and not owning draught power increases pig production while reducing other livestock production. This different response is due to the household-specific calibration of the production functions. As a result this household type gains more from increasing the amount of purchased feed in pig production than in other livestock production.

\section{Village level impact of trade liberalization: supply response and income distribution}

The previous section focused on differences across household types. This discussion illustrated that differences in household endowment and access to off-farm employment affect household production response. Finding opposing production responses to agricultural price changes and employment changes, begs the question what the aggregate village supply response to trade liberalization is. A second question that comes to mind is which household gains most from the trade liberalization. The second part of this section therefore discusses the income and welfare impacts of trade liberalization.

\subsection{Village agricultural supply response}

As with analyzing household response, we look at price and employment effects of trade liberalization separately before assessing the combined effect on the village marketed surplus (Table 11). We also computed the change in total marketed surplus of rice, summing one and two season rice.

The discussion of household response was cast in terms of percentage changes, ignoring the different sizes of the household groups. As indicated in Table 2, the two household groups with an outside link are larger than the two household groups lacking such a link. This difference in size affects the contribution of each household group to the village marketed surplus. The household type with an outside link and owning draught power forms the largest group (295 households), and the village marketed surplus follows the same pattern as the production response of this household group. 
Table 11: Village marketed surplus with trade liberalization

\begin{tabular}{|c|c|c|c|}
\hline & $\begin{array}{c}\text { Price changes } \\
\text { (1) }\end{array}$ & $\begin{array}{c}\text { Employment changes } \\
\text { (2) }\end{array}$ & $\begin{array}{l}\text { Trade liberalization } \\
\text { (1) and (2) combined }\end{array}$ \\
\hline \multicolumn{4}{|c|}{ Village marketed surplus (\% change compared to base): } \\
\hline One season rice & -5 & 63 & 73 \\
\hline Two season rice & 6 & -51 & -57 \\
\hline Rice & 2 & -14 & -15 \\
\hline Other crops & -3 & -6 & -8 \\
\hline Pig production & -16 & 2 & -13 \\
\hline Other livestock & 1214 & 2 & 1253 \\
\hline \multicolumn{4}{|c|}{ Composition of village marketed surplus ( $\%$ of total surplus): } \\
\hline One season rice & 13 & 32 & 25 \\
\hline Two season rice & 26 & 17 & 11 \\
\hline Other crops & 9 & 11 & 8 \\
\hline Pig production & 22 & 37 & 23 \\
\hline \multirow[t]{2}{*}{ Other livestock } & 30 & 3 & 32 \\
\hline & 100 & 100 & 100 \\
\hline
\end{tabular}

The change in agricultural prices following trade liberalization increases total exports of rice from the village, due to a shift to two season rice by the two largest household groups. This shift is induced by an increase in rice prices, with most other input prices remaining unaffected. This asymmetric price changes makes intensive rice cultivation more attractive. The increase in other livestock production is largely due to the explosion of the marketed surplus by the household owning draught power but lacking an outside province link (see also Table 6), which is only partly tempered by the relatively small size of this household group (100 households).

The increased labor demand following trade liberalization has the opposite impact of agricultural price changes. The increasing shadow wages result in a shift to less intensive rice cultivation, and total rice exports from the village drop by 14 percent. Differences across household types in marketed surplus of other livestock almost cancel each other, leaving a very modest 2 percent increase.

Combining price and employment changes, the impact of increased employment dominates the marketed surplus of crops, while agricultural price changes dominate the impact on the marketed surplus of livestock activities. The net result is a decrease in rice exports from the village, while exports from other crops also drop with 8 percent. Declines in household production response of other crops were modest for all three scenarios. But after summing over all households, and accounting for increased household consumption following the increased incomes, the reduction becomes significant at village level.

The explosion in marketed surplus of other livestock in percentage terms raises questions on the size of the other livestock sector following trade liberalization. Table 2 indicates a limited share of other livestock in production in the village SAM, which amounts to 3 percent of the value of village marketed surplus. The explosion of other livestock production results in ten-fold increase in its 
contribution to the value of village marketed surplus. Simultaneously rice production drops in importance, accounting for 50 percent of marketed surplus in the SAM, which drops to 36 percent following trade liberalization. In terms of total marketed surplus, the village thus can be characterized as shifting from rice-producing to a livestock producing village.

\subsection{Household income and welfare}

The discussion so far has focused on changes in agricultural production which was found to shift considerably in response to changes in prices and employment. The impact of these changes on household income and welfare has been left untouched. Since growing income inequalities are a rising concern in China, we now turn to analyzing income and welfare. Again, we split the impact of trade liberalization in prices, before looking at their combined impact.

Table 12: Changes in full income and welfare following trade liberalization per household and village total

\begin{tabular}{|c|c|c|c|}
\hline & $\begin{array}{c}\text { Prices } \\
\text { (1) }\end{array}$ & $\begin{array}{c}\text { Employment } \\
\text { (2) }\end{array}$ & $\begin{array}{c}\text { Trade } \\
\text { (1) and (2) } \\
\text { combined }\end{array}$ \\
\hline \multicolumn{4}{|l|}{ Full income per household (\% change): } \\
\hline No draught power, no outside province link & 2.5 & 4.2 & 7.0 \\
\hline Draught power, no outside province link & 4.9 & 1.9 & 7.0 \\
\hline No draught power, outside province link & 1.3 & 8.0 & 9.3 \\
\hline Draught power, outside province link & 3.2 & 3.7 & 6.1 \\
\hline Total $^{1}$ increase in full income ( $\%$ change): & 2.7 & 4.9 & 7.4 \\
\hline \multicolumn{4}{|l|}{ Welfare increase per household ( $E V, 1,000$ yuan): } \\
\hline No draught power, no outside province link & 0.3 & 0.5 & 0.9 \\
\hline Draught power, no outside province link & 0.7 & 0.3 & 1.0 \\
\hline No draught power, outside province link & 0.2 & 1.3 & 1.5 \\
\hline Draught power, outside province link & 0.6 & 0.8 & 1.2 \\
\hline Total $^{1}$ welfare increase $(\mathrm{EV}, 1,000$ yuan): & 313.9 & 630.0 & 910.0 \\
\hline
\end{tabular}

${ }^{1}$ Computed as the sum over all households.

The upper-part of Table 12 presents percentage changes in full income per household. The household lacking an outside link but owning draught power benefits most from the agricultural price changes. This is a direct result of its activity composition (see Table 2), which focuses on agricultural production. Not surprising given its orientation on outside province migration, the household with an outside link but lacking draught power benefits least from the price change, but most from the increased employment opportunities. The total increase in full income is considerable for all households, ranging from 6 to 9 percent.

The lower part of Table 12 presents the welfare increase per household, measured by the equivalent variation. The pattern is similar as with the changes in full income. The households owning draught power are oriented towards agriculture and benefit most from the price changes, while the households involved in outside province migration benefit most from the increased employment opportunities. 
The total increase in welfare following trade liberalization varies between 900 and 1,500 yuan per household.

Table 13: Full income and cash income per adult equivalent following trade liberalization (,000 yuan)

\begin{tabular}{|c|c|c|c|c|}
\hline & Base & Prices & Employment & Trade \\
\hline \multicolumn{5}{|l|}{ Full income per adult equivalent: } \\
\hline No draught power, no outside province link & 4.3 & 4.4 & 4.5 & 4.6 \\
\hline Draught power, no outside province link & 4.3 & 4.5 & 4.4 & 4.6 \\
\hline No draught power, outside province link & 3.8 & 3.9 & 4.1 & 4.2 \\
\hline Draught power, outside province link & 4.3 & 4.4 & 4.4 & 4.5 \\
\hline Village average & 4.1 & 4.2 & 4.3 & 4.4 \\
\hline \multicolumn{5}{|c|}{ Full income per adult equivalent adjusted for migration: } \\
\hline No draught power, no outside province link & 4.4 & 4.5 & 4.6 & 4.7 \\
\hline Draught power, no outside province link & 4.3 & 4.5 & 4.4 & 4.6 \\
\hline No draught power, outside province link & 5.0 & 5.0 & 5.5 & 5.6 \\
\hline Draught power, outside province link & 5.5 & 5.7 & 5.8 & 5.9 \\
\hline \multicolumn{5}{|c|}{ Cash income per adult equivalent adjusted for migration: } \\
\hline No draught power, no outside province link & 0.8 & 0.8 & 0.9 & 0.9 \\
\hline Draught power, no outside province link & 0.8 & 0.8 & 0.8 & 0.8 \\
\hline No draught power, outside province link & 1.7 & 1.7 & 1.9 & 1.9 \\
\hline Draught power, outside province link & 1.1 & 1.2 & 1.2 & 1.2 \\
\hline
\end{tabular}

The full income and welfare per household indicate that although all households benefit from the trade liberalization, welfare gains are concentrated with the households with access to outside province migration. To assess the impact on the income distribution within the village, Table 13 presents different measures of income per capita. The upper-part presents the full income per adult equivalent, which is the household size measured in male-equivalent consumer units ignoring the absence of migrated household members. As can be expected given the egalitarian distribution of land, income differences are not huge. Note that in terms of income per adult, the household type involved in outside province migration and lacking draught power is the poorest household. Since this household benefits most from the trade liberalization, this would suggest that access to rural-urban migration reduces the income differences.

Measuring income, however, is a tricky matter. The middle part of Table 13 presents an alternative income measure, adjusting household size for the absence of migrants ${ }^{6}$ This turns the ranking of households up-side down and the income distribution appears much less egalitarian. Using his measure, households involved in outside province migration are the richer households to start with and income differences grow with trade liberalization. Accounting for reduced consumption demand with an increase in migration thus increases both the gains from trade liberalization as the widening of income differences.

\footnotetext{
${ }^{6}$ The household survey data only include remittances received from migrants, we thus lack data on the actual income received by the migrants. The remittances are net of the consumption expenditures by the migrants made while being away. We can thus deduct the time which migrants are absent from the consumption needs of the households.
} 
Through incorporating farm-household models in the village model we are able to measure the full income of households, including the consumption of farm output. Measurements of income or poverty generally need to rely on recorded expenditures, and we therefore included a measure of the cash income of households in the bottom part of Table 13. The cash income is measured as the total expenditures on consumption goods, purchased inside or outside the village. Comparing these numbers to the full income measures shows the importance of the consumption of farm produced output. Comparing across scenarios, the impact of trade liberalization appears limited when measured in terms of cash expenditures. Again, because of the increase in migrants, the household with an outside link and lacking draught power gains most from trade liberalization.

\section{Conclusions}

In this study we employed an innovative village equilibrium model, which fully accounts for the impact of nonseparability on household production and consumption response. This allowed us to analyze the impact of trade liberalization on agricultural supply response and off-farm employment, while accounting for household consumption decisions. To our knowledge this is the first empirical village level study that accounts for nonseparability of household production and consumption decisions, both in construction of village SAM, the structure of the village model and the calibration of household production and utility functions. The village model is used to analyze the impact of trade liberalization which was quantified through a macro level GTAP model. We analyzed the impact of price changes and labor demand, the two major pathways through which international trade affects households.

Analyzing the impact of changes in agricultural prices we find that labor endowments determine the choice for more or less intensive rice cultivation. Two household groups shift to less intensive one season rice production, since an increase in shadow wages outweighs the increase in rice prices. The other two household groups move in the opposite direction moving to more intensive rice production. Since the latter two groups are larger, the village marketed surplus of rice increases in response to the agricultural price changes. The village marketed surplus of other livestock also increases, mainly due to an explosion of this activity by one type of household which uses a lot of external inputs and little labor in producing other livestock. The rise in output prices increases the availability of cash, allowing this household to expand its production.

Analyzing the impact of an increase in employment we find that it matters whether the increased demand for labor is concentrated in the coastal cities, or spread more evenly throughout the provinces. Comparing household production response to an increase in outside province employment, we find that households having access to migration move to less labor intensive rice production, while households lacking access to migration move to more labor intensive cultivation. The response of the latter group of households is triggered by a decreased price of animal traction services, due to the lessintensive cultivation of households involved in migration. If both inside and outside province employment increases, one type of household qualitatively changes it production response. A rise in its shadow wage combined with a further decrease in demand for animal traction, has the household owning draught power but lacking an outside province link to shift to one season rice as well. The net impact of an increase in employment is a reduction in the village-marketed surplus of rice. 
The two pathways through which trade affects households thus have an opposite impact on household production response. Assessing the combined effect at household level, the dominant aspect of trade liberalization depends on household endowments and on production activities. We furthermore found that a strong involvement in off-farm employment does not necessarily imply that the employment aspect of trade liberalization dominates household response, hampering a ex ante judgment on the most relevant aspect of trade liberalization for a specific household type.

Rising income inequalities are a growing concern in China. Analyzing the income and welfare impacts of trade liberalization we find that although all households benefit, the households involved in outside province migration gain most. Whether this improves or worsens within-village income distribution depends on whether one accounts for the reduction in consumption demand when household members migrate. If the consumption impact of migration is ignored, income distribution improves with trade liberalization. Accounting for the absence of migrants leads to the opposite conclusion, with the richer households gaining most from trade liberalization. Thus although ruralurban migration can transfer benefits from economic growth in the coastal provinces to inland provinces, asymmetric access to migration implies that the rising rural-urban income differences are transferred as well.

The findings of this study clearly illustrate the advantages of using a village equilibrium model that allows for household-specific production. Opposite movements in production, reflecting different household endowments, temper the village level production response. The impact of differential household endowments would have been missed with a sector level modeling of production which separates firm production decisions from household consumption decisions. The analysis also highlights the importance of local links in transmitting shocks throughout the village economy, despite the village being well integrated in agricultural output and input markets.

Given the relatively standard data needed for the model, the most important limitation for applying this methodology elsewhere is the amount of detail at village level, which comes at the cost of coverage. A relevant question is whether the results of the case study village are representative for villages outside Jiangxi province. An interesting avenue for answering this question it to use the model as a laboratory for understanding mechanisms and for formulating testable hypotheses on the impact of trade on household incomes and production decisions. Using data collected in other villages, these hypotheses could then be tested to see whether the findings from the village equilibrium model can be generalized.

\section{References}

Benjamin, D., and Brandt, L. (1999). "Markets and inequality in rural China: parallels with the past" in The American Economic Review, Vol. 89, No. 2: 292-295.

Bowlus, A. J., and Sicular, T. (2003). "Moving Towards Markets? Labor Allocation in Rural China" in Journal of Development Economics, Vol. 71: 561-583.

Cook, S. (1999). "Surplus labour and productivity in Chinese agriculture: evidence from household survey data" in The Journal of Development Studies, Vol. 35, No. 3: 16-44. 
de Janvry, A., Fafchamps, M., and Sadoulet, E. (1991). "Peasant household behavior with missing markets: some paradoxes explained" in Economic Journal, Vol. 101: 1400-1417.

Démurger, S., Sachs, J. D., Woo, W. T., Bao, S., and Chang, G. (2002). "The relative contributions of location and preferential policies in China's regional development: being in the right place and having the right incentives" in China Economic Review, Vol. 13: 444-465.

Diao, X., Fan, S., and Zhang, X. (2003). "China's WTO accession: impacts on regional agricultural income - a multi-region, general equilibrium analysis" in Journal of Comparative Economics, Vol. 31: 332-351.

European Commission. (2002). "The EC's Proposal for Modalities in the WTO Agriculture Negotiations." Ref. 625/02, Directorate-General for Trade / Directorate-General for Agriculture, Brussels.

Gilbert, J., and Wahl, T. (2003). "Labor market distortions and China's WTO accession package: an applied general equilibrium assessment" in Journal of Comparative Economics, Vol. 31: 774794.

Hare, D. (1999). “'Push' versus 'pull' factors in migration outflows and returns: determinants of migration status and spell duration among China's rural population" in The Journal of Development Studies, Vol. 35, No. 3: 45-72.

Ho, P. (2001). "Who Owns China's Land? Policies, Property Rights and Deliberate Institutional Ambiguity" in The China Quarterly, Vol., No. 166: 394-420.

Huang, J., Li, N., and Rozelle, S. (2003). "Trade Reform, Household Effects, and Poverty in Rural China" in American Journal of Agricultural Economics, Vol. 85, No. 5: 1292-1298.

Huang, J., and Rozelle, S. (2004). "Agricultural Development and Policies in China." in F. W. v. Tongeren and J. Huang (eds.) China's food economy in the early 21 st Century; Development of China's food economy and its impact on global trade and on the EU. Agricultural Economics Research Institute (LEI), Report 6.04.04, The Hague.

Jones, D. C., Li, C., and Owen, A. L. (2003). "Growth and regional inequality in China during the reform area" in China Economic Review, Vol. 14: 186-200.

Löfgren, H., and Robinson, S. (1999). "Nonseparable farm household decisions in a computable general equilibrium model" in American Journal of Agricultural Economics, Vol. 81, No. 3: 663-670.

Murphy, R. (2000). "Migration and Inter-household Inequality: Observations from Wanzai County, Jiangxi" in China Quarterly, Vol. 0, No. 164: 965-82.

Park, A., Brandt, L., and Giles, J. (2003). "Competition under credit rationing: theory and evidence from rural China" in Journal of Development Economics, Vol. 71, No. 2: 463-495.

Poncet, S. (2003). "Measuring Chinese domestic and international integration" in China Economic Review, Vol. 14: 1-21.

Qiao, F., Lohmar, B., Huang, J., Rozelle, S., and Zhang, L. (2003). "Producer Benefits from Input Market and Trade Liberalization: the Case of Fertilizer in China" in American Journal of Agricultural Economics, Vol. 85, No. 5: 1223-1227.

Rozelle, S., Guo, L., Shen, M., Hughart, A., and Giles, J. (1999a). "Leaving China's farms: survey results of new paths and remaining hurdles to rural migration" in The China Quarterly, Vol., No. 158: 367-393.

Rozelle, S., Taylor, J. E., and deBrauw, A. (1999b). "Migration, remittances, and agricultural productivity in China" in The American Economic Review, Vol. 89, No. 2: 287-291.

Taylor, J. E., and Adelman, I. (1996). Village economies: the design estimation and use of villagewide economic models, Cambridge University Press, Cambridge, etc.

Taylor, J. E., and Adelman, I. (2003). "Agricultural Household Models: Genesis, Evolution, and Extensions" in Review of Economics of the Household, Vol. 1: 33-58.

van Tongeren, F. W., and Huang, J. (2004). "China's food economy in the early 21 st Century; Development of China's food economy and its impact on global trade and on the EU.", Agricultural Economics Research Institute (LEI), Report 6.04.04, The Hague. 
van Tongeren, F. W. and H. van Meijl (2004). "Beyond the Uruguay Round: An evaluation of Doha Development Round proposals", in F. W. v. Tongeren and J. Huang (eds.) China's food economy in the early 21st Century; Development of China's food economy and its impact on global trade and on the EU. Agricultural Economics Research Institute (LEI), Report 6.04.04, The Hague.

Winters, L. A. (2002). "Trade, Trade Policy and Poverty: What Are the Links?" in The World Economy, Vol. 25: 1339-67.

Zeller, M., Sharma, M., Ahmed, A. U., and Rashid, S. (2001). "Group Based Financial Institutions for the Rural Poor in Bangladesh. An Institutional and Household Level Analysis." Research Report 120, IFPRI, Washington D.C. 